\title{
Analysis and DNA interaction of the profluralin herbicide
}

\author{
Kamila Morawska ${ }^{1} \cdot$ Katarzyna Jedlińska $^{2}$. Sylwia Smarzewska ${ }^{1} \cdot$ Radovan Metelka $^{3}$ - Witold Ciesielski ${ }^{1}$. \\ Dariusz Guziejewski ${ }^{1}$ (i)
}

Received: 24 July 2018 / Accepted: 7 February 2019 / Published online: 6 April 2019

(c) The Author(s) 2019

\begin{abstract}
The increasing use of pesticides is a major health issue. There is therefore a need for improved analytical methods and more knowledge on the interaction of pesticides with living organisms. Here, we developed the analysis of profluralin in water and soils by cyclic voltammetry, square-wave voltammetry and square-wave adsorptive stripping voltammetry. We also studied the interaction between profluralin and double-stranded DNA. Results of cyclic voltammetric studies indicate that the reduction processes have an irreversible and adsorption-like character, as a possible consequence of the reduction of nitro groups of profluralin. Quantification was found linear from 60 to $800 \mathrm{nmol} \mathrm{L}^{-1}$ with a detection limit of $17 \mathrm{nmol} \mathrm{L}^{-1}$ using square-wave adsorptive stripping voltammetry. Results of interactions with double-stranded DNA from salmon sperm revealed that profluralin forms a complex with DNA by electrostatic binding. Values of Gibbs free energy confirmed that formation of profluralin-DNA complex is spontaneous and favourable.
\end{abstract}

Keywords Profluralin · Cetyltrimethylammonium bromide · Double-stranded DNA · Square-wave adsorptive stripping voltammetry $\cdot$ Herbicide

\section{Introduction}

Herbicides are a specific type of pesticides which are used in agricultural, forest and wild-land ecosystems to reduce or to inhibit the normal growth rate of weeds. Since they can be accumulated in crops, the problem of bioaccumulation of toxins in the environment and in the food chains is significant (Samghani and Hossein Fatemi 2016; Oller-Ruiz et al. 2018). Numerous herbicides can cause different types of

Electronic supplementary material The online version of this article (https://doi.org/10.1007/s10311-019-00865-1) contains supplementary material, which is available to authorized users.

Sylwia Smarzewska

sylwia.smarzewska@chemia.uni.lodz.pl

$\triangle$ Dariusz Guziejewski

dguziejewski@uni.lodz.pl

1 Department of Inorganic and Analytical Chemistry, University of Lodz, Tamka 12, 91-403 Lodz, Poland

2 Faculty of Materials Science and Ceramics, AGH University of Science and Technology, Mickiewicza 30, 30-059 Cracow, Poland

3 Department of Analytical Chemistry, University of Pardubice, 53210 Pardubice, Czech Republic health effects ranging from skin rashes, through respiratory problems or even to birth defects or cancer. Thus, the analysis of herbicides and their impact on environmental pollution is an important field of analytical chemistry research (Valle et al. 2018; Gill et al. 2018). Herbicides belonging to the group of dinitroanilines are extensively used in the selective control of weeds due to their broad spectrum of function, chemical stability, efficiency of the action and relatively low direct toxicity. An example of such compounds is profluralin ( $N$-(cyclopropylmethyl)-2,6-dinitro- $N$-propyl4-(trifluoromethyl)aniline, Supplementary Material, Fig. S1). Profluralin is used for preemergence control of annual grasses and small-seeded broadleaf weeds, especially in cotton, soybeans and peanuts, but also in sunflower, cabbage, cauliflower, tomato and others. This herbicide kills weeds by penetrating their roots and stems (Xia et al. 2014; Helling 1976). The decomposition of profluralin occurs in soil (Carringer et al. 1975; Camper et al. 1977), water (Kearney et al. 1977) and by microorganisms (Stralka and Camper 1981). Depending on type of soil, a half-life of this herbicide is approximately 80 to 160 days. Since profluralin is strongly adsorbed to organic matter, it could be transferred into agricultural products such as vegetables, fruits and cereals with potential risk of food pollution. Profluralin is very 
toxic to honeybees and fish when placed directly in water. Fortunately, it is practically non-toxic in small doses to birds and mammals (EPA 2016). In case of large doses in the rats' organisms, ataxia, decreased respiratory rate, salivation, prostration, hyperactivity or dyspnea was observed. Overexposure to profluralin may cause irritation of skin, eyes and mucous membrane for humans (PMEP 2007).

To date, analytical methods based on mostly gas chromatography-tandem mass spectrometry (GC-MS/MS) were utilized for the determination of profluralin in plants (Taha and Gadalla 2017; Hou et al. 2016; Bernardi et al. 2016), honey (Shendy et al. 2016), nutraceuticals (Nieto-García et al. 2015; Páleníková et al. 2015) and cereals (He et al. 2015).

Traditionally, mercury electrodes were the most widely used sensors in electroanalysis due to their excellent electrochemical properties. To reduce the amount of toxic mercury needed for the analytical procedure, the mercury film electrodes on various conductive substrates were developed. Since the mercury film electrodes have a larger surface-tovolume ratio than conventional mercury drop electrodes, obtained stripping signals are more intensive and sharper because of faster diffusion of the analyte within the thin mercury film (Economou and Fielden 2003; Smarzewska et al. 2018). Therefore, sensitivity and selectivity of the detection are greatly enhanced. Moreover, simple construction, low costs and possibility of mercury film regeneration resulted in general acceptance of film electrodes as effective electroanalytical tools. Some of the mercury film electrodes inconveniences related to preparation and their use were solved by a renewable, silver amalgam film electrode designed by research group from Cracow (Baś and Kowalski 2002). The principle of this working electrode is based on formation of a cylindrical amalgam film at the surface of silver wire, which is refreshed before each measurement via pulling the wire through reservoir of silver amalgam. Very small consumption of silver amalgam not exceeding $10 \mu \mathrm{L}$ and long-term stability with more than two thousand measurement cycles (Baś 2006; Piech et al. 2008a) make this electrode design environmentally friendly and consistent with green chemistry demands. Excellent properties of silver amalgam film electrode have been successfully utilized in the determinations of metals (Baś 2006; Piech et al. 2008a, b), vitamins (Baś et al. 2011), drugs (Smajdor et al. 2015; Smarzewska et al. 2017a, b), hormones (Smajdor et al. 2016a, 2017), steroids (Smajdor et al. 2016b) and pesticides (Smarzewska et al. 2017c; Guziejewski et al. 2017, 2018). Initial experiments revealed a distinct electrochemical activity of the profluralin and enabled its determination at the glassy carbon electrode (Smarzewska et al. 2017c). Herein, we continue the profluralin investigation using silver amalgam film electrode with the aim of improving the sensitivity and linearity of its electrochemical detection and of separating overlapping signal, which was not possible at glassy carbon electrode. Likewise, the square-wave voltammetry technique was used due to its excellent features, such as high sensitivity and possibility of application in broad mechanistic, kinetic and analytical studies (Mirceski et al. 2013; Guziejewski et al. 2015; Smarzewska et al. (2016); Smarzewska and Ciesielski 2014; Karadas-Bakirhan et al. 2016). New procedure was successfully applied for sensitive determination of profluralin in environmental, water and soil samples. Moreover, interaction between profluralin and double-stranded DNA, dsDNA was explored.

\section{Materials and methods}

\section{General voltammetric procedure, instrumentation and software}

All voltammetric experiments were carried out using a $\mu$ Autolab Type III from Eco Chemie, the Netherlands, with GPES software, i.e. General Purpose Electrochemical System, version 4.9. A classical three-electrode system consisting of a reference electrode, i.e. $\mathrm{Ag} / \mathrm{AgCl} / 3 \mathrm{~mol} \mathrm{~L}^{-1} \mathrm{KCl}$, a counter electrode $-\mathrm{Pt}$ wire, and a working electrode, i.e. a renewable silver amalgam film electrode from mtm-anko, Cracow, Poland, was used. The construction details and properties of the working electrode have been described previously (Baś and Kowalski 2002). Quantitative measurements were performed using square-wave voltammetry or square-wave adsorptive stripping voltammetry techniques and the standard addition method. The amalgam film of the working electrode was refreshed before each measurement. The refreshing procedure involves two steps: pulling up the silver wire inside the electrode holder through a silver amalgam reservoir and then pushing it back outside. Measurements were carried out in deaerated solutions. Oxygen dissolved in solutions was removed by passing pure argon for at least $5 \mathrm{~min}$ prior to each voltammetric scan. All electrochemical experiments were conducted at the ambient temperature of the laboratory. A digital $\mathrm{pH} / \mathrm{mV} /$ ion meter from Metrohm, $827 \mathrm{pH}$ lab, was used for preparation of the buffer solutions. Water was demineralized in PURELAB UHQ from Elga LabWater, UK.

\section{Solutions}

Profluralin standard 99\% was purchased from Dr. Ehrenstorfer $\mathrm{GmbH}$. All the chemicals used for preparation of buffer solutions were from POCH, Poland. Surfactants sodium dodecyl sulphate and cetyltrimethylammonium bromide and dsDNA, e.g. double-stranded salmon sperm deoxyribonucleic acid, were purchased from Sigma-Aldrich. Organic solvents were supplied by Avantor, Poland. Solutions were 
purged with pure argon, Linde Gas, before voltammetric analyses. A fresh stock solution of $1 \mathrm{mmol} \mathrm{L}^{-1}$ profluralin was prepared weekly by dissolving $3.47 \mathrm{mg}$ of the compound in $10 \mathrm{~mL}$ of ethanol. Working solutions of lower concentrations were freshly prepared by the appropriate dilution of the stock standard solution. dsDNA solution was prepared in PBS buffer $\mathrm{pH}$ 7.4. Britton Robinson buffers of different $\mathrm{pH}$ values were made by the addition of $0.2 \mathrm{~mol} \mathrm{~L}^{-1}$ sodium hydroxide to mixture of phosphoric, boric and acetic acid, $0.04 \mathrm{~mol} \mathrm{~L}^{-1}$ of each acid. The final $\mathrm{pH}$ was checked using a $\mathrm{pH}$ meter, Metrohm.

\section{Samples}

The samples: Ner river water, tap water and soil from Rawa Mazowiecka, central Poland, were used without any preseparation or pre-concentration. Spiked tap and river water solutions were prepared as follows: $1 \mathrm{~mL}$ volume of profluralin appropriately diluted stock solution was transferred to a $10-\mathrm{mL}$ flask and filled up to the mark with tap or river water. Final concentration of profluralin in tap and river water samples was equal to 1.0 -sample A, 10-sample B and $100 \mu \mathrm{mol} \mathrm{L}{ }^{-1}$ - sample C. Spiked soil samples were prepared as follows: appropriate amount of profluralin working solution was added to $5 \mathrm{~g}$ of samples 1 and 2 or $10 \mathrm{~g}$ of sample 3. The samples were left to dry in the dark. Subsequently, $5 \mathrm{~mL}$ of ethanol was added to the samples, vigorously mixed for $10 \mathrm{~min}$ and then filtrated. Final concentration of profluralin in soil samples was equal to $0.1,1.0$ and $10.0 \mathrm{ppm}$ for samples 1, 2 and 3, respectively. To record the square-wave and square-wave adsorptive stripping voltammograms of the spiked samples, $1 \mathrm{~mL}$ of the above sample solution was transferred into the voltammetric cell containing $9 \mathrm{~mL}$ of the supporting electrolyte. Successive additions of profluralin standard solution were added to the electrochemical cell with a micropipette. The profluralin concentration in spiked samples was analysed using the standard addition method. Voltammograms were recorded after each addition. Recoveries were calculated after three replicate experiments.

\section{Results and discussion}

\section{Preliminary studies}

The choice of supporting electrolyte is an important stage in electrochemical studies. The composition of the supporting electrolyte affects the properties of the solution and the solution-electrode interface, which influence the kinetics and thermodynamics of the charge transfer process (Kissinger and Heinemann 1996). The effect of various supporting electrolytes such as borax and Britton-Robinson buffers on the profluralin peak current was investigated using the silver amalgam film electrode. Reduction signals of the profluralin were not observed in $\mathrm{pH}$ lower than 6.5 in the examined potential range. The highest profluralin signals were observed in Britton-Robinson buffer $\mathrm{pH}$ 8.5, see Fig. 1a, which was chosen for further studies.

With increasing $\mathrm{pH}$, profluralin signals shift towards more negative potentials. The plots of $E_{\mathrm{p}}$ versus $\mathrm{pH}$ were found linear in the examined $\mathrm{pH}$ range with slopes equal to 52 and $55 \mathrm{mV} \mathrm{pH}^{-1}$ for peak $1, E_{\mathrm{p}}$ ca. $-0.3 \mathrm{~V}$ and peak $2, E_{\mathrm{p}}$ ca. $-0.4 \mathrm{~V}$, respectively. These values are very close to theoretical value of $59 \mathrm{mV} \mathrm{pH}^{-1}$, so it can be assumed
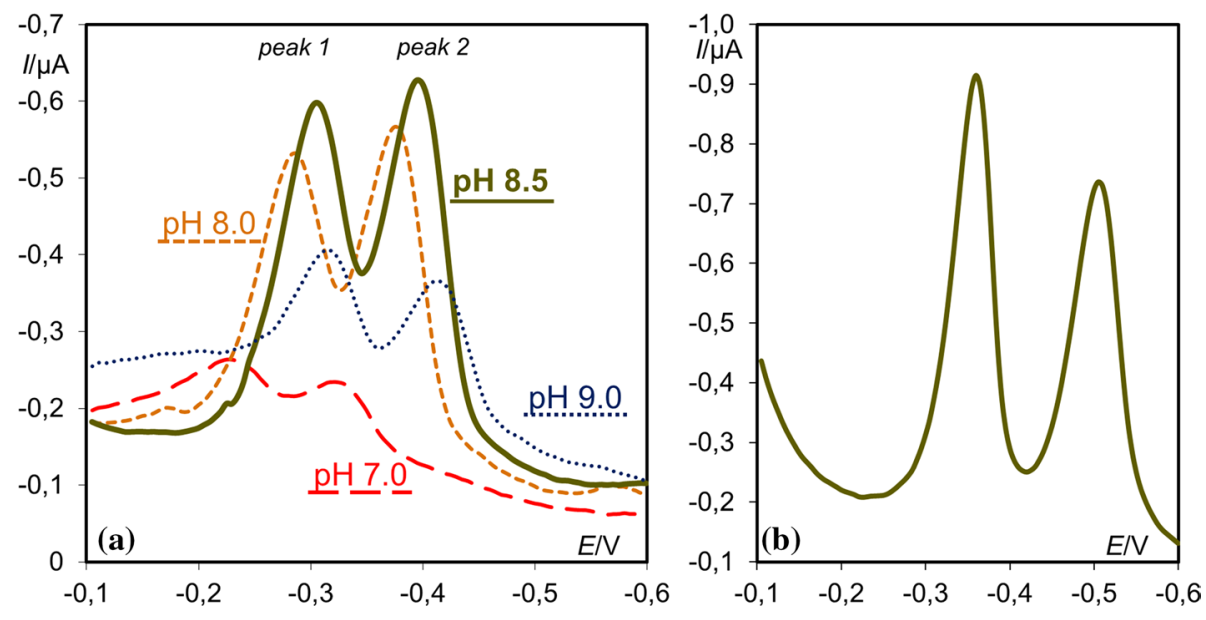

Fig. 1 Square-wave voltammograms of profluralin recorded in Britton-Robinson buffers, $c_{\text {profluralin }}=4.0 \times 10^{-6} \mathrm{~mol} \mathrm{~L}^{-1}(\mathbf{a})$; squarewave voltammograms of profluralin recorded in Britton-Robinson buffer $\mathrm{pH} 8.5$ containing $10 \% v$ ethanol and $1 \mathrm{mmol} \mathrm{L}^{-1}$ cetyltrimethylammonium bromide, i.e. $2 \% v, c_{\text {profluralin }}=7.0 \times 10^{-6} \mathrm{~mol} \mathrm{~L}^{-1}(\mathbf{b})$. It depicts that the highest profluralin signals were observed in $\mathrm{pH} 8.5$; moreover, the reduction signals of profluralin recorded by means of square-wave voltammetry were shifted towards less positive potentials with the increase in $\mathrm{pH}$. Separation of peaks was achieved when cetyltrimethylammonium bromide was used 
that the examined signals resemble processes in which equal numbers of protons and electrons are involved. As the standard solution of profluralin was prepared in ethanol, it was examined whether addition of ethanol, e.g. $0.1-30 \% v$, to supporting electrolyte influences the morphology and height of observed signals. It was observed that the highest signals were recorded when supporting electrolyte contained $10 \%$ of ethanol.

In the next step, the possibility of separation of superimposed profluralin signals was examined. Various surfaceactive compounds were tested for this purpose (Guziejewski et al. 2017). Better separation of peaks was achieved when cetyltrimethylammonium bromide was used. It was found that the optimal amount \%v of cetyltrimethylammonium bromide in supporting electrolyte is equal to $2 \%$, i.e. $c_{\text {cetyltrimethylammonium bromide }}=1 \mathrm{mmol} \mathrm{L}^{-1}$; see Fig. $1 \mathrm{~b}$. This phenomenon is connected with adsorption of surface-active compound at the electrode surface, which leads to the structure changes in the electrode/solution interface. Depending on the structure and overall charge of the surfactant, some assistance in other molecules adsorption or co-adsorption as well as solvation effects in the aggregates impacts on the changes in analyte redox potentials. Hence, the presence of surface-active compounds provides amelioration of electroanalysis in terms of sensitivity and selectivity. Several literature reports can be found on the use of surfactants (Atta et al. 2007; Corona-Avendaño et al. 2010) for improved analytical features of determination of biologically active compounds. After optimization of supporting electrolyte composition, some selection of square-wave voltammetric parameters was examined as described in Supplementary Material. Also an insight into profluralin electrode mechanism is given therein.

\section{Analytical application}

After evaluation of redox signals of the profluralin, peak 1 was chosen for analytical purposes. Since the separated peaks are of the same origin, i.e. electrochemical reduction of nitro group, choice between first or second peak was not relevant for analytical studies. Quantitative measurements were performed using square-wave voltammetry or squarewave adsorptive stripping voltammetry, chosen supporting electrolyte and optimal experimental parameters of the electrochemical detection. Calibration curves for the squarewave voltammetric techniques were constructed by plotting the peak current against the profluralin concentration. The cathodic peak current increased linearly with the concentration of profluralin from 0.4 to $7.0 \mu \mathrm{mol} \mathrm{L}^{-1}$, see Fig. $\mathrm{S} 3 \mathrm{a}$, and from 60 to $800 \mathrm{nmol} \mathrm{L}^{-1}$ for square-wave voltammetry and square-wave adsorptive stripping voltammetry, respectively. The characteristics of the calibration plots are provided in Table 1. The limits of quantification, LOQ and detection, LOD were calculated from the calibration curves as $k \mathrm{SD} / b$, where $k$ is 3 and 10 for LOQ and LOD, respectively, SD is a standard deviation of the intercept, and $b$ a slope of the calibration curve.

The reliability of the proposed methods was investigated by assaying this herbicide in tap water, river water-Ner and soil samples. Series of spiked samples were used to further evaluate the accuracy of the proposed method. Standard addition method was used to determine profluralin in spiked samples. Example of obtained square-wave voltammetric responses for soil sample is shown in Fig. S3b. As can be seen, components of the sample do not interfere with the voltammetric peak of profluralin. The data related to the recovery curves in tap water, river water and soil samples are shown in Table 2. Values of recovery, calculated for all the samples, pointed that the components of the matrices do not affect the analytical sensitivity. Therefore, it can be concluded that the proposed procedures can be easily and successfully employed in the determination of profluralin.

\section{Profluralin-dsDNA interaction}

Since the concept of intercalation into DNA was first formulated by Lerman in 1961 (Lerman 1961), it has become widely recognized that many biologically active compounds correlate their biological activities with the ability of
Table 1 Quantitative determination of profluralin in Britton-Robinson buffer $\mathrm{pH} 8.5$

\begin{tabular}{lll}
\hline & Square-wave voltammetry & $\begin{array}{l}\text { Square-wave adsorp- } \\
\text { tive stripping voltam- } \\
\text { metry }\end{array}$ \\
\hline $\begin{array}{l}\text { Linear range (mol L } \\
\text { Slope of calibration graph }\end{array}$ & $4.0 \times 10^{-7}-7.0 \times 10^{-6}$ & $6.0 \times 10^{-8}-8.0 \times 10^{-7}$ \\
$\quad\left(\mathrm{~A} \mathrm{~L} \mathrm{~mol}{ }^{-1}\right)$ & 0.31 & 1.3 \\
Intercept (A) & $2.2 \times 10^{-7}$ & $1.5 \times 10^{-7}$ \\
Correlation coefficient & 0.997 & 0.999 \\
LOD (mol L & $2.9 \times 10^{-8}$ & $1.7 \times 10^{-8}$ \\
LOQ (mol L & $9.7 \times 10^{-8}$ & $5.7 \times 10^{-8}$ \\
\hline
\end{tabular}

Basic statistic data of the regression line, together with limit of detection, i.e. LOD and limit of quantification, i.e. LOQ, evaluation based on triplicate measurements 
Table 2 Analysis of spiked water samples towards profluralin electrochemical detection, SWV square-wave voltammetry, SWAdSV square-wave adsorptive stripping voltammetry

\begin{tabular}{|c|c|c|c|c|}
\hline $\begin{array}{l}\text { Added } \\
(\mu \mathrm{mol} \\
\left.\mathrm{L}^{-1}\right)\end{array}$ & $\begin{array}{l}\text { Found } \\
(\mu \mathrm{mol} \\
\left.\mathrm{L}^{-1}\right)\end{array}$ & Precision (\%) & Recovery (\%) & Technique \\
\hline \multicolumn{5}{|c|}{ Tap water } \\
\hline 100 & 105 & 5.96 & 105 & \multirow[t]{3}{*}{ SWV } \\
\hline 10.0 & 10.6 & 8.02 & 106 & \\
\hline 5.00 & 4.76 & 7.46 & 95.2 & \\
\hline 100 & 109 & 9.58 & 109 & \multirow[t]{3}{*}{ SWAdSV } \\
\hline 10.0 & 10.8 & 7.56 & 108 & \\
\hline 1.00 & 1.04 & 8.41 & 104 & \\
\hline \multicolumn{5}{|c|}{ River water } \\
\hline 100 & 102 & 9.15 & 102 & \multirow[t]{3}{*}{ SWV } \\
\hline 10.0 & 11.1 & 9.75 & 111 & \\
\hline 5.00 & 5.04 & 4.99 & 101 & \\
\hline 100 & 104 & 4.24 & 104 & \multirow[t]{3}{*}{ SWAdSV } \\
\hline 10.0 & 10.3 & 6.78 & 103 & \\
\hline 1.00 & 1.18 & 5.22 & 118 & \\
\hline \multicolumn{5}{|c|}{ Soil (in ppm) } \\
\hline 0.100 & 0.103 & 4.70 & 103 & \multirow[t]{2}{*}{ SWAdSV } \\
\hline 1.00 & 0.992 & 3.00 & 99.2 & \\
\hline 10.0 & 10.6 & 1.25 & 106 & SWV \\
\hline
\end{tabular}

interaction with DNA (Waring1972). Interactions between DNA and chemical and physical agents, present in the environment, often result in mutations of the DNA nucleotide sequence (Blackburn and Gait 1990; Zhang et al. 2012). Plant protection products, dyes or compounds responsible for air pollution are just some examples of chemicals which may interact with DNA. In electroanalysis, such interaction may be also utilized for DNA determination. Since profluralin is very toxic to aquatic organisms, double-stranded DNA, i.e. dsDNA, isolated from fish sperm was chosen to examine the interaction between profluralin and DNA. In the presence of dsDNA, profluralin signals decreased and shifted to more negative potential values, e.g. Fig. 2, indicating the electrostatic binding mode (Xu and Bard 1995; Carter and Bard 1987). Profluralin signal loss may be caused by change in the equilibrium concentration of free profluralin because of profluralin-dsDNA interaction (Erdem and Ozsoz 2001) or due to formation of profluralin-dsDNA adduct with large molecular weight with subsequent decrease in the apparent diffusion coefficient (Wang et al. 2003). Linear dependence between peak current and scan rate was observed for profluralin and profluralin in the presence of dsDNA. Linear dependence, namely $I_{\mathrm{p}}[\mu \mathrm{A}]=5.73 \times 10^{-3} \nu\left[\mathrm{mV} \mathrm{s}^{-1}\right]+0.134$ $[\mu \mathrm{A}], R^{2}=0.980$ and $I_{\mathrm{p}}[\mu \mathrm{A}]=1.31 \times 10^{-3} \nu\left[\mathrm{mV} \mathrm{s}^{-1}\right]+0.597$ $[\mu \mathrm{A}], R^{2}=0.999$, respectively, indicates adsorption-controlled nature of both observed phenomena. This evidence was confirmed with the linear logarithmic plot $I_{\mathrm{p}}$ versus $v$.

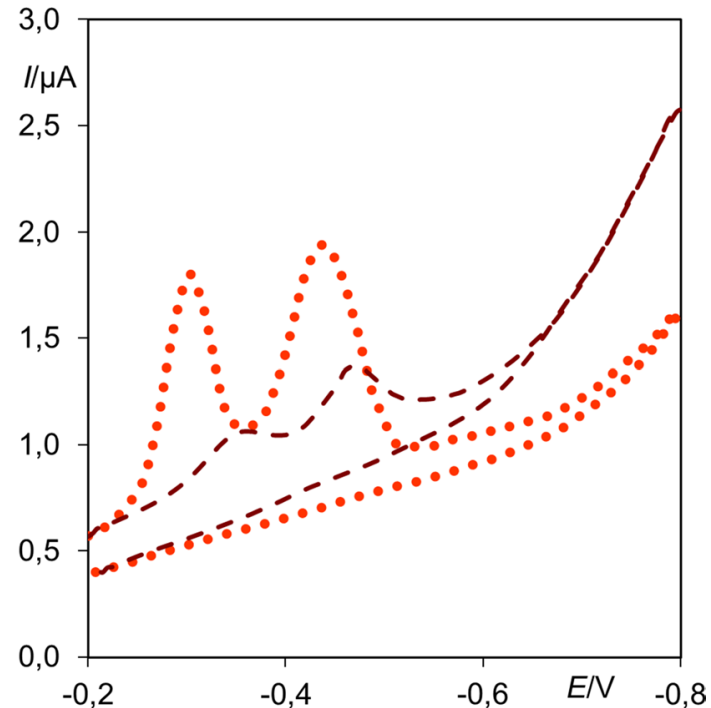

Fig. 2 Cyclic voltammograms of $1.0 \times 10^{-4} \mathrm{~mol} \mathrm{~L}^{-1}$ profluralin in the absence-dotted, and presence-dashed line, of $5.0 \mathrm{ppm}$ doublestranded DNA. Supporting electrolyte: phosphate-buffered saline buffer $\mathrm{pH} 7.4$; scan rate $100 \mathrm{mV} \mathrm{s}^{-1}$. It depicts that in the presence of double-stranded DNA, profluralin signals decreased and shifted to more negative potential values, which indicates the electrostatic binding mode

Therefore, profluralin and profluralin-DNA complex adsorption at the working electrode surface can be assumed (NosalWiercińska et al. 2018).

According to observed phenomena, it was examined whether profluralin-dsDNA interaction may be used to develop dsDNA determination method, where calibration curve is based on profluralin signal loss caused by increasing dsDNA concentration. It was stated that indirect determination is possible in the range from 1.0 to $10.0 \mathrm{ppm}$ of dsDNA, e.g. Fig. S4. Dependence between recorded peak current and dsDNA concentration can be described with calibration curve $I_{\mathrm{p}}[\mathrm{A}]=-6.02 \times 10^{-8}\left[\mathrm{~A} \mathrm{ppm}^{-1}\right] \cdot c_{\mathrm{dsDNA}}$ $[\mathrm{ppm}]+6.00 \times 10^{-7}[\mathrm{~A}]$. Limit of detection and limit of quantification were estimated as shown in the previous section. Limit of detection (LOD) and limit of quantification (LOQ) were found to be 0.17 and $0.57 \mathrm{ppm}$, respectively. Further information on the interaction between profluralin and dsDNA is given in Supplementary Material.

\section{Conclusion}

We have demonstrated that the tested herbicide is electrochemically active at a silver amalgam film electrode. Electrochemical reduction of profluralin is irreversible and controlled by an adsorption. The voltammograms recorded in the alkaline medium of Britton-Robinson buffer of $\mathrm{pH} 8.5$ consisted of two cathodic signals associated with the reduction of 
nitro groups in the profluralin molecule. Addition of cetyltrimethylammonium bromide surfactant enabled the separation of overlapping signals, and it was possible to develop electroanalytical procedure for profluralin determination in concentration ranges of $0.4-7.0 \mu \mathrm{mol} \mathrm{L}^{-1}$ and $60-800 \mathrm{nmol} \mathrm{L}^{-1}$ using square-wave voltammetry and square-wave stripping voltammetry, respectively. The method was also applied successfully in the determination of profluralin in soil and water samples. High sensitivity, low detection limit and very good repeatability together with excellent recovery make the silver amalgam film electrode suitable for accurate determination of profluralin in environmental samples. In comparison with our previous publication (Smarzewska et al. 2017c), we have found that using those new conditions, linear response towards profluralin determination can be significantly extended. Moreover, using the developed method, difficulties connected to overlapping signal may be omitted with the use of surfactant. Additionally, we have proposed a possibility of determination in the new type of environmental sample that was not possible before. It can serve as an alternative to expensive chromatographic methods for routine analysis of environmental samples at least for screening purposes. Moreover, as profluralin is highly toxic to fish, its interaction with double-stranded DNA, i.e. dsDNA, isolated from salmon sperm was examined. Those studies have shown that interaction between profluralin and dsDNA takes place via electrostatic binding mode. It was revealed that dsDNA forms complex where four molecules of profluralin are attached to DNA strand. Values of binding constant and Gibbs free energy change degree revealed that such complex is stable and its formation is a spontaneous process. It was also stated that decrease of profluralin signals in the presence of dsDNA may be used for indirect determination of dsDNA with LOD of $0.17 \mathrm{ppm}$.

Acknowledgements This work was supported by the University of Lodz, Poland, under Grant for young investigators No. B1711100001602.02.

OpenAccess This article is distributed under the terms of the Creative Commons Attribution 4.0 International License (http://creativecommons.org/licenses/by/4.0/), which permits unrestricted use, distribution, and reproduction in any medium, provided you give appropriate credit to the original author(s) and the source, provide a link to the Creative Commons license, and indicate if changes were made.

\section{References}

Atta NF, Darwish SA, Khalil SE, Gala IA (2007) Effect of surfactants on the voltammetric response and determination of an antihypertensive drug. Talanta 72:1438-1445. https://doi.org/10.1016/j. talanta.2007.01.053

Baś B (2006) Refreshable mercury film silver based electrode for determination of chromium(VI) using catalytic adsorptive stripping voltammetry. Anal Chim Acta 570:195-201. https:// doi.org/10.1016/j.aca.2006.04.013

Baś B, Kowalski Z (2002) Preparation of silver surface for mercury film electrode of prolonged analytical application. Electroanalysis 14:1067-1071. https://doi.org/10.1002/1521-4109(20020 8)14:15/16\%3c1067:AID-ELAN1067\%3e3.0.CO;2-5

Baś B, Jakubowska M, Górski Ł (2011) Application of renewable silver amalgam annular band electrode to voltammetric determination of vitamins C, B1 and B2. Talanta 84:1032-1037. https ://doi.org/10.1016/j.talanta.2011.03.006

Bernardi G, Kemmerich M, Ribeiro LC, Adaime MB, Zanella R, Prestes OD (2016) An effective method for pesticide residues determination in tobacco by GC-MS/MS and UHPLC-MS/ MS employing acetonitrile extraction with low-temperature precipitation and d-SPE clean-up. Talanta 161:40-47. https:// doi.org/10.1016/j.talanta.2016.08.015

Blackburn MG, Gait MJ (1990) Nucleic acids in chemistry and biology. IRL Press, New York

Camper ND, Stralka K, Skipper HD (1977) Aerobic and anaerobic degradation of profluralin and trifluralin. J Environ Sci Health B 15:457-473

Carringer RD, Weber JB, Monaco TJ (1975) Adsorption-desorption of selected pesticides by organic matter and montmorillonite. J Agric Food Chem 23:568-572. https://doi.org/10.1021/jf601 99a037

Carter MT, Bard AJ (1987) Voltammetric studies of the interaction of tris(1,10-phenanthroline)cobalt(III) with DNA. J Am Chem Soc 109:7528-7530. https://doi.org/10.1021/ja00258a046

Corona-Avendaño S, Ramírez-Silva MT, Palomar-Pardavé M, Hernández-Martínez L, Romero-Romo M, Alarcón-Ángeles G (2010) Influence of CTAB on the electrochemical behavior of dopamine and on its analytic determination in the presence of ascorbic acid. J Appl Electrochem 40:463-474. https://doi.org/10.1007/s1080 0-009-0017-x

Economou A, Fielden PR (2003) Mercury film electrodes: developments, trends and potentialities for electroanalysis. Analyst 128:205-212. https://doi.org/10.1039/B201130C

Erdem A, Ozsoz M (2001) Voltammetry of the anticancer drug mitoxantrone and DNA. Turk J Chem 25:469-475

Gill JPK, Sethi N, Mohan A, Datta S, Girdhar M (2018) Glyphosate toxicity for animals. Environ Chem Lett 16:401-426. https://doi. org/10.1007/s10311-017-0689-0

Guziejewski D, Mirceski V, Jadresko D (2015) Measuring the electrode kinetics of surface confined electrode reactions at a constant scan rate. Electroanalysis 27:67-73. https://doi.org/10.1002/elan.20140 0349

Guziejewski D, Smarzewska S, Metelka R, Nosal-Wiercińska A, Ciesielski W (2017) Improved electroanalytical characteristics for flumetralin determination in the presence of surface active compound. Monatsh Chem 148:555-562. https://doi.org/10.1007/ s00706-017-1918-8

Guziejewski D, Morawska K, Popławski T, Metelka R, Ciesielski W, Smarzewska S (2018) Lactofen-electrochemical sensing and interaction with dsDNA. Electroanalysis 30:94-100. https://doi. org/10.1002/elan.201700472

He Z, Wang L, Peng Y, Luo M, Wang W, Liu X (2015) Multiresidue analysis of over 200 pesticides in cereals using a QuEChERS and gas chromatography-tandem mass spectrometry-based method. Food Chem 169:372-380. https://doi.org/10.1016/j.foodc hem.2014.07.102

Helling CS (1976) Dinitroaniline herbicides in soils. J Environ Qual 5:1-15. https://doi.org/10.2134/jeq1976.00472425000500010001x

Hou X, Lei S, Guo L, Qiu S (2016) Optimization of a multi-residue method for 101 pesticides in green tea leaves using gas chromatography-tandem mass spectrometry. Rev Bras Farmacogn 26:401-407. https://doi.org/10.1016/j.bjp.2016.03.007 
Karadas-Bakirhan N, Gumustas M, Uslu B, Ozkan SA (2016) Simultaneous determination of amlodipine besylate and rosuvastatin calcium in binary mixtures by voltammetric and chromatographic techniques. Ionics 22:277-288. https://doi.org/10.1007/s11581-015-1534-8

Kearney PC, Isensee AR, Kontson A (1977) Distribution and degradation of dinitroaniline herbicides in an aquatic ecosystem. Pestic Biochem Physiol 7:242-248. https://doi.org/10.1016/0048-3575(77)90015-3

Kissinger PT, Heinemann WR (1996) Laboratory techniques in electroanalytical chemistry. Taylor \& Francis, New York

Lerman LS (1961) Considerations in the interaction of DNA and acridines. J Mol Biol 3:18-30

Mirceski V, Gulaboski R, Lovric M, Bogeski I, Kappl R, Hoth M (2013) Square-wave voltammetry: a review on the recent progress. Electroanalysis 25:2411-2422. https://doi.org/10.1002/elan.201300369

Nieto-García AJ, Romero-González R, Garrido Frenich A (2015) Multipesticide residue analysis in nutraceuticals from grape seed extracts by gas chromatography coupled to triple quadrupole mass spectrometry. Food Control 47:369-380. https://doi.org/10.1016/j.foodc ont.2014.07.041

Nosal-Wiercińska A, Kaliszczak W, Grochowski M, Wiśniewska M, Klepka T (2018) Effects of mixed adsorption layers of 6-mercaptopurine-Triton X-100 and 6-mercaptopurine-Tween 80 on the double layer parameters at the mercury/chlorates(VII) interface. J Mol Liq 253:143-148. https://doi.org/10.1016/j.molliq.2018.01.041

Oller-Ruiz A, Garrido I, Vinas P, Campillo N, Fenoll J, Hernandez-Cordoba M (2018) Reliable analysis of chlorophenoxy herbicides in soil and water by magnetic solid phase extraction and liquid chromatography. Environ Chem Lett 16:1077-1082. https://doi.org/10.1007/ s10311-018-0725-8

Páleníková A, Martínez-Domínguez G, Arrebola FJ, Romero-González R, Hrouzková S, Frenich AG (2015) Multifamily determination of pesticide residues in soya-based nutraceutical products by $\mathrm{GC} /$ MS-MS. Food Chem 173:796-807. https://doi.org/10.1016/j.foodc hem.2014.10.100

Pesticide Management Education Program (PMEP) (2007) Cornell University, Profluralin (Tolban) herbicide profile. http://pmep.cce. cornell.edu/profiles/herb-growthreg/naa-rimsulfuron/profluralin/ herb-prof-profluralin.html. Accessed 15 Jan 2018

Piech R, Baś B, Kubiak WW (2008a) The cyclic renewable mercury film silver based electrode for determination of molybdenum(VI) traces using adsorptive stripping voltammetry. Talanta 76:295-300. https ://doi.org/10.1016/j.talanta.2008.02.038

Piech R, Baś B, Kubiak WW (2008b) The cyclic renewable mercury film silver based electrode for determination of manganese(II) traces using anodic stripping voltammetry. J Electroanal Chem 621:43-48. https://doi.org/10.1016/j.jelechem.2008.04.008

Samghani K, Hossein Fatemi M (2016) Developing a support vector machine based QSPR model for prediction of half-life of some herbicides. Ecotoxicol Environ Saf 129:10-15. https://doi. org/10.1016/j.ecoenv.2016.03.002

Shendy AH, Al-Ghobashy MA, Mohammed MN, Gad Alla SA, Lotfy HM (2016) Simultaneous determination of 200 pesticide residues in honey using gas chromatography-tandem mass spectrometry in conjunction with streamlined quantification approach. J Chromatogr A 1427:142-160. https://doi.org/10.1016/j.chroma.2015.11.068

Smajdor J, Piech R, Rumin M, Paczosa-Bator B (2015) New high sensitive hydrocortisone determination by means of adsorptive stripping voltammetry on renewable mercury film silver based electrode. Electrochim Acta 182:67-72. https://doi.org/10.1016/j.elect acta.2015.09.057

Smajdor J, Piech R, Rumin M, Paczosa-Bator B, Smajdor Z (2016a) High sensitive voltammetric levothyroxine sodium determination on renewable mercury film silver based electrode. J Electrochem Soc 163:605-609. https://doi.org/10.1149/2.1431607jes

Smajdor J, Piech R, Paczosa-Bator B (2016b) A novel method of high sensitive determination of prednisolone on renewable mercury film silver based electrode. Electroanalysis 28:394-400. https://doi. org/10.1002/elan.201500262

Smajdor J, Piech R, Paczosa-Bator B (2017) Voltammetric determination of drospirenone on mercury film electrode. J Electrochem Soc 164:311-315. https://doi.org/10.1149/2.0541706jes

Smarzewska S, Ciesielski W (2014) Electroanalysis of pindolol on a GCE modified with reduced graphene oxide. Anal Meth 6:5038-5046. https://doi.org/10.1039/c4ay00648h

Smarzewska S, Pokora J, Leniart A, Festinger N, Ciesielski W (2016) Carbon paste electrodes modified with graphene oxides-comparative electrochemical studies of thioguanine. Electroanalysis 28:1562-1569. https://doi.org/10.1002/elan.201501101

Smarzewska S, Guziejewski D, Leniart A, Ciesielski W (2017a) Nanomaterials vs amalgam in electroanalysis: comparative electrochemical studies of lamotrigine. J Electrochem Soc 164:B321-B329. https:// doi.org/10.1149/2.0221707jes

Smarzewska S, Metelka R, Festinger N, Guziejewski D, Ciesielski W (2017b) Comparative study on electroanalysis of fenthion using silver amalgam film electrode and glassy carbon electrode modified with reduced graphene oxide. Electroanalysis 29:1154-1160. https ://doi.org/10.1002/elan.201600710

Smarzewska S, Jasińska A, Ciesielski W, Guziejewski D (2017c) First electroanalytical studies of profluralin with square wave voltammetry using glassy carbon electrode. Electroanalysis 29:244-248. https ://doi.org/10.1002/elan.201600562

Smarzewska S, Metelka R, Baś B, Vytřas K (2018) Recent applications of silver amalgam electrodes for analysis of pharmaceuticals and vitamins. Curr Med Chem 25:4138-4151. https://doi.org/10.2174/09298 67324666170920143245

Stralka KA, Camper ND (1981) Microbial degradation of profluralin. Soil Biol Biochem 13:33-38. https://doi.org/10.1016/00380717(81)90099-7

Taha SM, Gadalla SA (2017) Development of an efficient method for multi residue analysis of 160 pesticides in herbal plant by ethyl acetate hexane mixture with direct injection to GC-MS/MS. Talanta 174:767-779. https://doi.org/10.1016/j.talanta.2017.06.080

United States Environmental Protection Agency (EPA) (2016) Regional removal management levels for chemicals (RMLs). https://www. epa.gov/sites/production/files/2016-05/documents/summary_table _hq1_may_2016.pdf. Accessed 15 Jan 2018

Valle AL, Mello FCC, Alves-Balvedi RP, Rodrigues LP, Goulart LR (2018) Glyphosate detection: methods, needs and challenges. Environ Chem Lett. https://doi.org/10.1007/s10311-018-0789-5

Wang S, Peng T, Yang CF (2003) Electrochemical determination of interaction parameters for DNA and mitoxantrone in an irreversible redox process. Biophys Chem 104:239-248. https://doi.org/10.1016/S0301 $-4622(02) 00371-X$

Waring MJ (1972) The molecular basis of antibiotic action. Wiley, New York

Xia GH, Shen WJ, Wu B, Lu HY, Zhang R, Shen CY, Yu KY, Zhao ZY, Liu H, Liu SQ, Bian XH, Xu JY (2014) Analysis of 7 dinitroaniline residues in complex food matrices by GC-NCI/MS. Chromatographia 77:493-499. https://doi.org/10.1007/s10337-013-2618-0

$\mathrm{Xu}$ XH, Bard AJ (1995) Immobilization and hybridization of DNA on an aluminum(III) alkanebisphosphonate thin film with electrogenerated chemiluminescent detection. J Am Chem Soc 117:2627-2631. https ://doi.org/10.1021/ja00114a027

Zhang Q, Wang C, Liu W, Zhang X, Zhuang S (2012) Evidence for DNA-diquat interaction and cytotoxicity in in vitro rat cells. Environ Chem Lett 10:35-39. https://doi.org/10.1007/s10311-011-0325-3)

Publisher's Note Springer Nature remains neutral with regard to jurisdictional claims in published maps and institutional affiliations. 